\title{
Persepsi Guru dan Siswa Terhadap Implementasi Pembelajaran Daring Pada Masa Pandemik Covid-19 Di Sekolah Dasar
}

\author{
Yulia Purnama Sari ${ }^{1}$ \\ ${ }^{1}$ Sekolah Dasar 175 Simpang Kemini, Indonesia
}

\begin{tabular}{l} 
Article Info \\
\hline Article history: \\
Received Jul 13, 2020 \\
Revised Ags 16, 2020 \\
Accepted Sep 28, 2020 \\
\hline
\end{tabular}

Keywords:

Covid-19

Persepsi

Pembelajaran Daring

\begin{abstract}
ABSTRAK
Tujuan Penelitian: Tujuan penelitian ini yaitu untuk mencari gambaran pembelajaran daring yang telah dilakukan disekolah berdasarkan persepsi guru dan siswa.
\end{abstract}

Metode Penelitian: Penelitian ini menggunakan teknik analisis deskriptif. Penelitian ini berupaya untuk memberikan suatu gambaran terhadap suatu kondisi yang telah terjadi berdasarkan tanggapan dan pendapat dari narasumber. Sampel dalam penelitian ini berjumalah 25 orang siswa kelas 5 sekolah dasar yang telah melaksanakan pembelajaran daring. Instrumen yang digunakan berupa angket dan wawancara terstruktur.

Temuan Utama: Berdasarkan persepsi yang telah dikemukan narasumber menunjukan bahwa indikator yang dapat dinilai pada implementasi pembelajaran daring berupa ketersedian sarana dan prasarana serta keefektifan pembelajaran daring. Seluruh narasumber telah memiliki sarana dan prasarana berupa gawai untuk menunjang pembelajaran daring. Namun terdapat kendala berupa jaringan atau koneksi internet. $40 \%$ memiliki koneksi yang baik dan $60 \%$ memiliki koneksi yang terganggu. Sedangkan mengenai keefektifan belajar menunjukan bahwa 36\% atau sebanyak 9 siswa menyatakan menikmati proses pembelajaran daring, $44 \%$ atau sebanyak 11 siswa menyatakan kurang menikmati pembelajaran daring dan $20 \%$ atau sebanyak 5 orang siswa menyatakan tidak menikmati proses pembelajaran daring.

Keterbaruan Penelitian: Keterbaruan dalam penelitian ini berupa pemaparan tentang persepsi narasumber terhadap suatu kondisi yang secara tiba-tiba harus dilakukan, dimana tindakan tersebut berbeda dengan kebiasaan.

This is an open access article under the $\mathrm{CCBY-NC}$ license

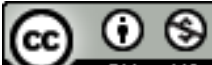

\section{Corresponding Author:}

Yulia Purnama Sari SDN 175/II Simpang Kemini,

Jalan Raya Simpang Kemini-Alai ilir, Bathin II Babeko, kab. Bungo, Indonesia Email: yuliapurnama@gmail.com

\section{PENDAHULUAN}

Akhir tahun 2019 dunia tengah digemparkan dengan munculnya wabah virus penyakit yang menjangkit pada manusia. Virus ini pertama kali muncul di wilayah kota wuhan yaitu bagian dari provinsi Hubei, China. An ongoing outbreak of pneumonia associated with a novel coronavirus, severe acute respiratory syndrome (SARS) coronavirus 2, was reported in Wuhan, Hubei Province, China, in December 2019 (1-3) [1]. Pada tanggal tanggal 12 februari WHO menamai virus ini coronavirus disease 2019 karena disebabkan oleh novel coronavirus. Penyebaran Covid-19 terus meluas dari pertama ditemukan hal ini karena penyebaran Covid-19 dapat melalu kontak atau interaksi antara satu dengan yang lain. Covid-19 memiliki 
penyebaran yang sangat cepat. As of March 12, 2020, coronavirus disease 2019 (COVID-19) has been confirmed in 125048 people worldwide, carrying a mortality of approximately $3 \cdot 7 \%, 1$ compared with a mortality rate of less than $1 \%$ from influenza [2]. Covid-19 terus menjadi sebuah perhatian mata dunia, setiap negara mengeluarkan berbagai kebijakan untuk melindungi setiap warga negaranya.

Sebagai negara yang masih dalam satu kawasan dengan china, indonesia juga memiliki resiko penyebaran Covid-19. Jumlah penduduk Indonesia yang mencapai 267 juta jiwa mengakibatkan kekhawatiran akan adanya penyebaran Covid-19 di Indonesia menjadi besar. Pada tanggal 2 maret 2020 untuk pertama kalinya di indonesia ditemukan warga negara indonesia terjangkit oleh Covid-19. Pemerintah melakukan segala upaya dalam membendung agar Covid-19 di indonesia tidak menyebar dengan cepat.

Penyebaran yang cepat membuat seluruh sektor strategis di indonesia terdampak secara luas, mulai dari sektor ekonomi, pariwisata, kesehatan, sosial budaya hingga pendidikan. Pemberlakuan PSBB dan protokol kesehatan mengakibatkan sektor pendidikan turut dalam menjalankan kebijakan tersebut. Hal ini dilakukan demi memutus rantai penyebaran virus dan menjaga keamanan serta keselamatan peserta didik dan tenaga pendidik [3]. Akibatnya pembelajaran tatap muka disekolah di kurangi atau bahkan ditiadakan. Pembelajaran dikelas diganti menggunakan pembelajaran dirumah melalui dalam jaraingan (Daring) atau pembelajaran jauh. Pembelajaran daring dilaksanakan dirumah dengan berbasis aplikasi melalui penggunaan TIK . Apalagi di tengah pandemi Covid-19, teknologi menjadi penghubung utama dalam proses belajar [4]. Guru dan para siswa yang didamping para orangtua melaksanakan pembelajaran dengan cara melalui gawai. Pembelajaran dalam jaringan (daring)/jarak jauh dilaksanakan untuk memberikan pengalaman belajar yang bermakna bagi siswa, tanpa terbebani tuntutan menuntaskan seluruh capaian kurikulum untuk kenaikan kelas maupun kelulusan [5]. Pembelajaran yang dimaksudkan berusaha melaksanakan pembelajaran yang menggali potensi diri siwa tanpa menjadikan siswa terbebani dengan standar pencapaian kompetensi.

Sesuai surat edaran mendikbud maka seluru daerah harus melaksanakan subtansi dari surat edaran tersebut, Dinas pendidikan kabupaten Bungo turut melaksanakan edaran tersebut untuk melaksanakan pembelajaran dirumah berbasis Daring atau pembelajaran jarak jauh. Pembelajaran secara daring merupakan cara baru dalam proses belajar mengajar yang memanfaatkan perangkat elektronik khususnya internet dalam penyampaian belajar [6]. Satuan pendidikan sebagai unsur pelaksana melaksanakan surat edaran tersebut sesuai dengan poin yang tertera. Selanjutnya Pembelajaran dilaksanakan secara daring berbasis aplikasi. Pelaksanan pembelajaran daring memiki kelebihan dan kekurangan. Pembelajaran daring memiliki manfaat seperti membangun komunikasi serta diskusi antara guru dengan anak, anak saling interaksi dan berdiskusi dengan satu dan lainnya, memudahkan anak berinteraksi dengan guru dan orang tua [7]. Belajar di rumah dapat difokuskan pada pendidikan kecakapan hidup antara lain mengenai pandemi Covid-19 [8]. Pembelajaran daring dimaksudkan untuk mencegah penyebaran Covid-19 namun disisi lain pengunaan gawai sebagai media belajar daring mengakibatkan munculnya berbagai masalah misalnya masalah sarana dan prasarana pendukung yaitu ketersedian gawai bagi setiap siswa, kondisi jaringan selular bagi siswa yang tinggal didaerah, kurang disiplinnya siswa dalam melaksanakan pembelajaran daring dan kurang maksimalnya peran orang tua dirumah sebagai instrumen pendukung terlaksananya pembelajaran dirumah.

Oleh karena itu peneliti akan melakukan analisis terhadap persepsi guru dan siswa terhadap implementasi pembelajaran daring pada masa pandemik Covid-19 di sekolah dasar?

\section{METODE PENELITIAN}

Penelitian ini menggunakan teknik analisis deskriptif. Penelitian ini berupaya untuk memberikan suatu gambaran terhadap suatu kondisi yang telah terjadi berdasarkan tanggapan dan pendapat dari narasumber. Sampel dalam penelitian ini berjumalah 25 orang siswa kelas 5 sekolah dasar yang telah melaksanakan pembelajaran daring. Instrumen penelitian ini menggunakan instrumen angket dan wawancara terstruktur. Pelaksanaan pengambilan data dilakukan setelah pembelajaran tatap muka dilaksanakan kembali.

\section{HASIL DAN PEMBAHASAN}

Pembelajaran dirumah melalui daring dilakasanakan dengan harapan dapat menghindarkan para guru dan siswa dari paparan Covid-19. Pembelajaran secara daring merupakan sebuah tantangan dan hal yang baru bagi dunia pendidikan. Pembelajaran daring tidak boleh semata-mata hanya menunaikan kalender pendidikan saja. Pelaksanaan pembelajaran daring harus tetap memberikan pengalaman belajar yang menarik dan bermakna bagi siswa. Artinya pembelajaran secara daring memerlukan sinergi yang baik antara pihak sekolah, guru, siswa dan orang tua. Persepsi yang akan menjadi indikator dalam penelitian ini berupa ketersedian sarana dan prasarana pendukung pembelajaran daring dan keefektifan pembelajaran daring. 


\subsection{Ketersedian sarana dan prasarana}

Kesiapan sarana dan prasarana dalam menunjang proses pembelajaran daring sangatlah penting. kurangnya sarana dan prasarana penunjang akan berakibat terhambatnya proses pembelajaran. Namun demikian pelaksanaan pembelajaran daring memiliki hambatan/kendala baik dari aspek sumber daya manusia maupun sarana-prasarana [9]. Pembelajaran secara daring dilaksanakan menggunakan aplikasi. Penggunaan aplikasi mengindikasikan perlunya siswa dan guru memiliki alat berupa gawai ataupun laptop. Berdasarkan hasil angket menunjukan bahwa $100 \%$ siswa telah memiliki gawai yang dapat digunakan untuk melakukan pembelajaran daring. Sementara itu pembelajaran daring dilakukan menggunakan aplikasi berbagi pesan Whatsapp (WA).

Penggunaan WA didasari pada penggunaan yang lebih mudah, sehingga seluruh siswa secara mudah dapat menggunakan tanpa ada kesulitan yang berarti. Selain itu penggunaan WA dapat memudahkan pembelajaran karena terdapat berbagai fitur seperti mengirim pesan teks, foto, dokumen berupa microsof word dan microsoft exel, voice note dan video call yang dapat memudahkan terjadinya interaksi secara real time antara guru dengan siswa. Pada dasarnya pembelajaran daring sangatlah ditentukan dengan koneksi/jaringan internet. Tanpa adanya sarana dan prasarana koneksi atau jaringan internet yang baik maka pembelajaran daring akan terhambat. Berdasarkan hasil angket menunjukan bahwa $40 \%$ atau 10 siswa telah memiliki koneksi atau jaringan internet yang baik sementara $60 \%$ atau 15 siswa belum memiliki koneksi atau jaringan internet yang baik.

Sementara berdasarkan hasil wawancara, pelaksanaan pembelajaran daring melalui aplikasi berbagi pesan WA dengan metode guru memberikan tugas sesuai dengan jadwal pelajaran yang telah ditentukan. Tugas yang dikirimkan dapat berupa pesan teks, video, ataupun mengirimkan dokumen berbentuk microsoft word. Selain itu guru memberikan perintah untuk mengerjakan dalam jangka waktu yang telah diberikan. Sementara itu metode pengumpulan tugas dapat berupa siswa mengirimkan hasil pekerjaannya berupa foto atau video kepada guru kelas. Pelaksanan pembelajaran masih terjadi interaksi antara guru dengan siswa seperti saling bertanya ataupun saling mengingatkan. Guru juga perlu menyadari bahwa setiap individu memiliki keistimewaan masing-masing. Setiap manusia memiliki kelebihan dan kekurangan masing-masing begitupun anak sekolah dasar [10]. Penggunaan aplikasi berbagi pesan dalam pembelajaran daring menjadi pilihan yang paling tepat dalam mewujudkan pembelajaran yang efektif. Selain siswa dapat terus belajar dan meningkatkan kompetensinya siswa juga dituntut untuk melatih sikap kejujuran, kedisiplinan dan rasa tanggung jawab.

\subsection{Keefektifan pembelajaran daring}

Keefektifan suatu kegiatan berarti ketepatan ataupun kesesuaian antara proses dengan hasil yang akan dicapai. Meskipun menjadi sebuah proses yang baru pembelajaran daring harus tetap dilaksanakan. Pembelajaran daring merupakan pembelajaran yang menggunakan jaringan internet dengan aksesibilitas, konektivitas, fleksibilitas, dan kemampuan untuk memunculkan berbagai jenis interaksi pembelajaran [11]. Pembahasan tentang keefektifan maka berkaitan erat dengan bagaimana suatu program dijalankan mulai dari proses perencanaan, pelaksanaan dan evaluasi.

Pembelajaran yang dilakukan berbasis teknologi merupakan sebuah keniscayaan ditengah pesatnya perkembangan zaman saat ini. Tantangan yang pertama datang dari adanya perubahan persepsi tentang belajar itu sendiri dan tantangan yang kedua datang dari adanya teknologi [12]. Akan tetapi proses perubahhan pembelajaran secara tatap muka ke pembelajaran jarak jauh berbasis teknologi tidak bisa berjalan secara tiba-tiba. Perlu adanya perencanaan yang matang agar pembelajaran yang dilakasanakan tidak mengesampingkan kualitas dan efektifitas pembelajaran. Tahap perencanaan meliputi berbagai bidang misalnya kesiapan guru dan siswa dan kesiapan sarana dan prasarana. Akan tetapi saat dalam kondisi darurat seperti pandemik Covid-19 diperlukan kebijakan yang tepat sehingga proses pembelajaran tetap dapat berlangsung tapi tetap berupaya menjaga guru dan siswa terhindar dari paparan Covid-19.

Sebagai seorang tenaga profesional, seorang guru harus mampu melakssanakan pembelajaran yang baik, efektif dan efisien sehingga tujuan pembelajaran dapat tercapai. Oleh karena itu seorang guru harus memiliki kompetensi pada bidang pendagogik. Kompetensi pedagogik terkait dengan kemampuan guru dalam mengajar, membimbing, dan juga memberikan teladan hidup kepada siswa [13]. Pedagogical competence with regard to the principles of learning [14]. Pedagogic competence and professional competence of teachers are closely related to the extent of teacher mastery of subject matter [15]. Selain Kemampuan guru pada ranah kompetensi pedagogik, pada masa pembelajaran daring seorang guru juga dituntut untuk secara profesional mampu menggunakan berbagai alat teknoologi penunjang pembelajaran daring misalnya gawai dan laptop. Sebenarnya kemampuan dalam bidang TIK harus menjadi kompetensi penunjang bagi guru bukan saja pada masa pandemik karena saat ini generasi yang tengah mereka didik adalah generasi $\mathrm{Z}$ yaitu generasi yang kesehariannya sangat dekat dengan kehidupan dunia maya melalui 
penggunaan gawai. Walaupun penggunaan gawai dapat mendukung pembelajaran daring, tetapi ada dampak negatif yang perlu mendapat perhatian dan diantisipasi yaitu penggunaan gawai yang berlebihan [16].

Berdasarkan hasil angket dan wawancara menunjukan bahwa guru kelas 5 telah memiliki kompetensi yang baik dalam pembelajaran daring baik pada kompetensi pedagogik maupun kemampuan penggunaan alat TIK penunjang pembelajaran daring. Guru tersebut mampu menggunakan laptop dan gawai secara baik dan dapat menggunakan aplikasi berbagi pesan yang telah disetujui sebagai sarana pembelajaran daring. Selain kompetensi guru, para siswa juga perlu menjadi perhatian khusus mulai dari ketersediaan alat TIK penunjang maupun kemapuan penggunaan alat TIK dan aplikasi sebgai sarana yang telah disetujui dalam pembelajaran.

Berdasarkan hasil angket dan wawancara kepada siswa menunjukkan bahwa $100 \%$ atau 25 orang siswa telah memiliki alat penunjang berupa gawai sebagai sarana pembelajaran daring. Gawai tersebut didapat mulai dari gawai siswa pribadi sebanyak $40 \%$ atau 10 siswa dari total 25 siswa dan sebanyak $60 \%$ atau sebanyak 15 siswa menggunakan gawai dari orangtua atau anggota keluarga yang lain. Selain itu data menunjukan bahwa $100 \%$ atau 25 orang siswa memilki kemampuan yang baik dalam menggunakan gawai terutama menggunakan aplikasi berbagi pesan yang telah disetujui untuk penggunaan pembelajaran daring yaitu Whatshap (WA).

Setelah memiliki perencanaan yang baik, tahap pelaksanaan merupakan tahapan yang sangat penting hal ini karena tahap pelaksanaan kan mencerminkan apakah pembelajaran yang telah dirancang dapat berjalan dengan baik dan memberikan dampak yang baik terhadap siswa. Berdasarkan hasil wawancara dengan guru dan siswa pembelajaran daring dilakukan dengan cara guru akan mengirimkan penjelasan materi yang akan menjadi topik pembahasan melalui pesan singkat, video singkat, dokumen maupun menggunakan voice note. Selama proses pembelajaran tengah dilakukan guru melakukan pembelajaran secara dua arah, siswa diminta bertanya terhadap penjelasan yang kurang dimengerti. Selanjutnya guru akan memberikan tugas yang harus dikerjakan oleh siswa. Siswa tetap diminta melaksanakan perintah dengan jujur dan penuh tanggung jawab. Setelah mengerjakan tugas, siswa diminta untuk mengirimkan tugas tersebut melalui foto yang dikirim dalam grub WA. Hal ini menunjukan bahwa peran guru sebagai fasilitator menjadi bagian yang sangat penting. Becoming facilitator, teachers help facilitate their students to meet the learning target, to learn independently and to find out solution upon the challenges they face within their learning context [17].

Selanjutnya guru melakukan evaluasi pembelajaran berupa meminta siswa untuk menyimpulkan pembelajaran secara singkat. Selain itu guru selalu memberikan nasihat kepada siswa untuk selalu bertanggung jawab dalam melaksanakan pembelajaran dan protokol kesehatan. Hal ini karena ditemui guru bahwa siswa sering tidak mengirimkan tugas yang telah diberikan dan meminta orang tua atau anggota keluarga untuk mengerjakan tugas.

Selain itu keefektifan belajar sangat berkaitan erat dengan kenyamanan siswa saat proses pembelajaran dilaksanakan. Kenyamanan siswa memegang peranan seberapa siswa dapat memberikan seluruh perhatiannya dalam proses belajar. Semakin nyaman seorang siswa dalam proses belajar maka kecenderungan untuk bersemangat dan termotivasi dalam proses pembelajaran tersebut. Berdasarkan hasil angket menunjukan bahwa $36 \%$ atau sebanyak 9 siswa menyatakan menikmati proses pembelajaran daring, $44 \%$ atau sebanyak 11 siswa menyatakan kurang menikmati pembelajaran daring dan $20 \%$ atau sebanyak 5 orang siswa menyatakan tidak menikmati proses pembelajaran daring.

Tabel 1. Persentase Kenyamanan Siswa

\begin{tabular}{clcc}
\hline No & \multicolumn{1}{c}{ Kategori } & Frekuensi & Persentase $(\%)$ \\
\hline 1 & Nyaman/Menikmati & 9 & 36 \\
2 & Kurang Nyaman/Menikmati & 11 & 44 \\
3 & Tidak Nyaman/Menikmati & 5 & 20 \\
\hline
\end{tabular}

Siswa yang masuk dalam kategori nyaman dan menikmati pembelajaran daring memiliki kecenderungan untuk dapat beradaptasi dengan metode pembelajaran baru. Para siswa memahami kondisi yang sedang terjadi. Selain itu, pendekatan pembelajaran yang dilakukan oleh guru dapat mereka pahami secara baik. Sementara siswa yang masuk dalam kategori kurang dan tidak menikmati memiliki kecenderungan untuk mudah merasa bosan. Mereka lebih nyaman dan senang saat pembelajaran dilaksanakan secara tatap muka sehingga dapat berinteraksi secara langsung dengan guru dan teman sejawat.

Pembelajaran yang baik merupakan pembelajaran yang dapat memberikan pembelajaran yang bermakna bagi siswa. Sehingga kenyamanan belajar siswa sebenarnya dapat dirancang dengan membuat pembelajaran yang menarik, walaupun dilakukan secara daring. Guru yang profesional dadat merancang pembelajaran dengan menggunakan metode dan pendekatan pembelajaran yang sesuai dengan kondisi yang mendukung suatu pembelajaran. Jika dalam proses belajar mengajar guru atau tenaga pengajar mampu menyajikan materi dengan desain menarik dan berkualitas maka siswa akan lebih tertarik untuk mempelajari 
materi tersebut $[18,19]$. Selain itu guru juga perlu dalam menjalin komunikasi yang baik dengan orang tua siswa. Peran orang tua memegang peranan yang sangat penting. pengawasan dan bimbingan orang tua pada saat pembelajaran daring juga dapat membantu guru agar siswa dapat nyaman dalam proses pembelajaran.

\section{KESIMPULAN}

Pembelajaran dengan menggunakan berbagai sarana berupa alat TIK merupakan sebuah hal yang tidak dapat dihindari. Akan tetapi pandemik Covid-19 memaksa peralihan dari pembelajaran tatap muka ke pembelajaran daring secara tiba-tiba. Berdasarkan paparan hasil angket dan wawancara yang telah dilakukan dapat disimpulkan bahwa pembelajaran daring yang telah dilakukan menimbulkan berbagai persepsi. Siswa lebih cenderung nyaman pada saat pembelajaran dilakukan secara tatap muka. Oleh karena itu guru perlu merancang pembelajaran secara menarik sehingga siswa dapat lebih menikmati pembelajaran secara daring. Pembelajaran yang menarik dapat dilakukan dengan menggunakan metode, pendekatan dan media pembelajaran yang tepat guna menarik perhatian siswa. Selain aspek kognitif, aspek afektif juga harus menjadi perhatian khusus karena pembelajaran secara daring sehingga siswa dapat menjalankan pembelajaran secara jujur dan bertanggung jawab. Selain itu, perlu adanya pengawasan dan bimbingan orang tua selama siswa melakukan pembelajaran dirumah guna menjamin terlaksanakan pembelajaran yang bermakna bagi siswa. Informasi yang diperoleh tidak dapat hanya sekedar pengetahuan yang diberikan oleh guru. Siswa harus membangun sendiri pengetahuannya.

\section{UCAPAN TERIMA KASIH}

Terima kasih atas seluruh responden karena telah bersedia menjadi sampel dalam penelitian ini, serta seluruh stakeholder yang barkaitan saya ucapakan terima kasih.

\section{REFERENSI}

[1] T. P. Velavan., and C. G. Meyer, "The COVID-19 epidemic," Tropical medicine \& international health, vol. 25, no. 3, pp. 278, 2020.

[2] S. Santoso, "Kompetensi Guru Dalam Menyusun LKPD Pembelajaran Jarak Jauh Di Masa Pandemi Covid 19", Jor. Eva. Edu, vol. 2, no. 2, pp. 44-49, 2021.

[3] N. H. Zhafira., Y. Ertika., dan Chairiyaton, "Persepsi Mahasiswa Terhadap Perkuliahan Daring Sebagai Sarana Pembelajaran Selama Masa Karantina Covid-19," Jurnal Bisnis Dan Kajian Strategi Manajemen, vol. 4, no. 1, 2020.

[4] S. Nadori and R. Hoyi, "Pengembangan Media Pembelajaran Fisika Menggunakan Software Aurora 3D Materi Pengukuran”, Jor. Eva. Edu, vol. 1, no. 3, pp. 78-82, 2021

[5] Kemendikbud. Surat Edaran Mendikbud Nomor 4 Tahun 2020 tentang Pelaksanaan Pendidikan Dalam Masa Darurat Coronavirus Disease (Covid-19). Jakarta: 2020.

[6] H. A. Rigianti, "Kendala Pembelajaran Daring Guru Sekolah Dasar Di Kabupaten Banjarnegara," Elementary School, vol. 7, no. 7, pp. 297-302. (2020)

[7] D. Ayuni., et al, "Kesiapan Guru Tk Menghadapi Pembelajaran Daring Masa Pandemi Covid-19," Jurnal Obsesi : Jurnal Pendidikan Anak Usia Dini, vol. 5, no. 1, pp. 414-421. 2020

[8] W. Aji., \& F. Dewi, “Dampak Covid-19 Terhadap Implementasi Pembelajaran Daring Di Sekolah Dasar,” Edukatif: Jurnal Ilmu Pendidikan, vol. 2, no. 1 , pp. 55-61. 2020.

[9] P. Wahyono., \& H. Husamah, "Guru Profesional Di Masa Pandemi Covid-19: Review Implementasi, Tantangan, Dan Solusi Pembelajaran Daring," Jurnal Pendidikan Profesi Guru, vol. 1, No. 1, pp. 51-65, 2020.

[10] U. Latifa, “Aspek Perkembangan pada Anak Sekolah Dasar: Masalah dan Perkembangannya,” Jurnal Academica, vol. 1, no. 2, 2017.

[11] M. Maison., D. A. Kurniawan., \& L. Anggraini, "Perception, attitude, and student awareness in working on online tasks during the covid-19 pandemic," Jurnal Pendidikan Sains Indonesia (Indonesian Journal of Science Education), vol. 9, no. 1, pp. 108-118, 2019.

[12] S. Hadijah, "Analisis Respon Siswa Dan Guru Terhadap Penggunaan Multimedia Interaktif Dalam Proses Pembelajaran Matematika," Jurnal Numeracy, vol. 5, no. 2. 2018.

[13] A. Qolik., \& S. C. Putro, "Hubungan Bakat Mekanik Dan Motivasi Keguruan Dengan Kompetensi Pedagogik Di Bidang Pemesinan Mahasiswa Program Studi S1 Pendidikan Teknik Mesin Ft-Um," Jurnal Teknologi Dan Kejuruan, vol. 33, no. 2, pp. 143-150. 2010.

[14] Asrial., et al, "Identification: The Effect Of Mathematical Competence On Pedagogic Competency Of Prospective Teacher". Humanities \& Social Sciences Reviews. Vol 7, No 4, , pp 85-92. 2019. https://doi.org/10.18510/hssr.2019.7413

Persepsi Guru dan Siswa Terhadap Implementasi Pembelajaran Daring Pada Masa ... (Yulia Purnama Sari) 
[15] Syahrial, "Etno-social knowledge: How does knowledge of basic school teachers in Indonesia?," Journal of Education and Learning (EduLearn), vol. 13, no. 4, pp. 583 588. 2019. DOI: 10.11591/edulearn.v13i4.13739

[16] A. Sadikin., \& A. Hamidah, "Pembelajaran Daring Di Tengah Wabah Covid-19," Biodik: Jurnal Ilmiah Pendidikan Biologi, vol. 06, no. 02 pp. 214 - 224. 2020.

[17] K. Y. Nugroho., \& D. F. Wulandari, "Constructivist Learning Paradigm as the Basis on Learning Model Development," Journal of Education and Learning, vol. 409, no. 4 pp. 410-415, 2017. DOI: 10.11591/edulearn.v11i4.6852

[18] E. M. Stefany, "Respon Siswa Pada Pengembangan Media Pembelajaran: Implementasi Pada Mata Pelajaran TIK Kelas Viii Di Smp Negeri 4 Denpasar,” Jurnal Ilmiah Edutic, vol. 2, no. 2, 2015.

[19] P. A. Ariyawati., J. Waluyo., \& J. Prihatin, "Analisis Respon Siswa Terhadap Model Pairs, Investigation And Communication (Pic) Dalam Pembelajaran IPA,” Jurnal Pembelajaran dan Pendidikan Sains, vol. 2 no. 3. pp. 9-15. 2017 